\title{
Self-medication with cannabidiol (CBD) and associated treatments in the self-care of anxiety in women from Mexico City: A qualitative study
}

\author{
Rafael Gutiérrez,' Leticia Vega'
}

1 Dirección de Investigaciones Epidemiológicas y Psicosociales, Instituto Nacional de Psiquiatría Ramón de la Fuente Muñiz, Ciudad de México, México.

\section{Correspondence: \\ Leticia Vega \\ Dirección de Investigaciones \\ Epidemiológicas y Psicosociales, \\ Instituto Nacional de Psiquiatría \\ Ramón de la Fuente Muñiz. \\ Calzada México-Xochimilco 101 \\ Col. San Lorenzo Huipulco, \\ 14370 Tlalpan, \\ Ciudad de México México. \\ Phone: +52 (55) $416-5197$ \\ Email: vegahle@imp.edu.mx}

Received: 9 July 2020

Accepted: 24 March 2021

Citation:

Gutiérrez, R., \& Vega, L. (2021). Self-medication with cannabidiol (CBD) and associated treatments in the self-care of anxiety in women from Mexico City: A qualitative study. Salud Mental, 44(6), 295-306.

DOI: $10.17711 /$ SM.0185-3325.2021.038

\begin{abstract}
Introduction. The popular use of marijuana and its components (THC and CBD) for medicinal purposes is often regarded as irresponsible and ignorant. However, in this paper, it is conceptualized and studied as medical knowledge of self-care, in which it is linked to different therapeutic knowledge from conventional and alternative medicine to treat anxiety. Objective. This article reports on a qualitative research project designed to analyze the practices and risks of self-medication with CBD, and its links with medical treatments and selfcare measures for dealing with anxiety in adult women in Mexico City. Method. Eleven adult women, mostly professionals, diagnosed with anxiety, participated in the study. In-depth interviews were conducted to learn how women use therapeutic resources to cope with anxiety in their everyday lives. The interviews were transcribed and analyzed using ATLAS ti 7 software. Results. Self-medication is part of a self-care process with several facets: the experience of symptoms, self-diagnosis, the use of various remedies (dosage and administration), and their evaluation. During this process, women use a range of medication, psychological therapies, herbalism, acupuncture, yoga, and sleep hygiene measures, including CBD, either as an alternative or an adjunct to biomedical pharmacology, with or without medical supervision. Certain risks were identified, such as the use of CBD that may be incorrectly labeled or interact dangerously with other self-prescribed substances. Discussion and conclusion. These results coincide with those of various authors who equate self-care with a first level of care, which has risks that could be reduced by controlling misleading marketing and developing professional medical services, which are trained and accessible to users, who could inform them about the medicinal use, scope and risks of CBD or THC for health.
\end{abstract}

Keywords: Self-care, self-medication, anxiety, CBD.

\section{RESUMEN}

Introducción. El uso popular de la marihuana y sus componentes (THC y CBD) con fines medicinales suele verse como irresponsable e ignorante. Sin embargo aquí se conceptúa y estudia como un saber médico de autoatención, donde se articula con distintos saberes terapéuticos de la medicina convencional y alternativa para atender la ansiedad. Objetivo. Se reporta una investigación cualitativa cuyo objetivo es analizar las prácticas y riesgos de automedicación de $\mathrm{CBD}$, y su articulación con tratamientos médicos y medidas de autocuidado, en la autoatención de la ansiedad de mujeres adultas de la CDMX. Método. Participaron 11 mujeres adultas, la mayoría profesionistas, con diagnósticos de ansiedad. Se ocupó la entrevista en profundidad para conocer cómo las mujeres usan recursos terapéuticos para atender la ansiedad en su vida cotidiana. Las entrevistas fueron transcritas y analizadas con la asistencia del software ATLAS ti 7. Resultados. La automedicación es parte de un proceso de autoatención, el cual tiene diferentes facetas: la vivencia de los síntomas, el autodiagnóstico, el uso de distintos remedios (dosificación y administración) y su evaluación. En este proceso las mujeres articulan distintos medicamentos, terapias psicológicas, herbolaria, acupuntura, yoga, medidas de higiene del sueño, incluido el consumo de CBD, ya sea como alternativa o complemento de la farmacología biomédica, con y sin supervisión médica. Se identificaron algunos riesgos como el uso de CBD que puede estar etiquetado de manera incorrecta o interactuar de manera peligrosa con otras sustancias automedicadas. Discusión y conclusión. Estos resultados coinciden con los de diversos autores que destacan la autoatención como un primer nivel de atención, que si bien tiene sus riesgos, éstos podrían disminuirse con la vigilancia de la comercialización engañosa y el desarrollo de servicios médicos profesionales y accesibles a los usuarios. Estos servicios deben informar y asesorar a los usuarios sobre el uso medicinal, alcances y riegos del CBD y THC para la salud.

Palabras clave: Autoatención, automedicación, ansiedad, CBD. 


\section{INTRODUCTION}

In Mexico, various psychoactive substances have been prohibited, such as mescaline, psilocybin, and tetrohydrocannabinol, present in the peyote plant (Lophopora williamsi), mushrooms (Psylocibe spp.) and marijuana (Cannabis sativa). Until a few years ago, the Mexican goverment only recognized the right of certain indigenous groups to collect, transport and consume these plants due to their religious, spiritual, and therapeutic uses and customs. Several reports document the use of these plants by traditional Mexican healers, whether they are shamans or healers, from various indigenous groups (Benítez, 1964; 1980; La Barre, 1969; Wasson, 1983). Some studies detail the therapeutic and propitiatory Otomí rituals, in which shamans, the repositories of ancestral knowledge, consume dry or soaked cannabis, which they call Santa Rosa or medicinita. This plant is specially grown so that only shamans can eat it in ceremonial contexts to establish contact with the sacred and serve as intermediaries between the divine and people, to restore health, ask for good harvests and ward off misfortune (Báez Cubero, 2012; Fagetti \& Reinoso Niche, 2019; Fagetti, Garrett Ríos, \& Reinoso Niche, 2017).

Although the Mexican goverment has restricted the medicinal use of psychoactive plants to certain indigenous groups, it has failed to prevent their expansion to mestizo populations in urban contexts. The ethnographic studies of Guzmán Chávez (2013) have found that throughout Mexico there are various collectives of mestizos who use these plants in ceremonial contexts in urbanized settings, under the supervision of indigenous shamans or herbalists or their disciples, mestizos born in cities. He documents the emergence of a church and various groups engaged in the cult of ayahuasca (a psychoactive plant of Brazilian origin) in eight urban centers in the country and their alliances with the cult of other plants (such as peyote and San Pedro). He describes the assimilation of their consumption rituals, as well as their organization to provide the substances, distribute them and ensure their proper use among members. The latter are mostly middle- and upper-middle-class. They are university students and professionals pursuing spiritual-personal development or seeking to cure psychological traumas or problems of addiction to cocaine, alcohol, or drugs.

Previous research has highlighted the prevalence of psychoactive substances in ceremonial contexts to restore health in indigenous and mestizo communities in urban environments. However, many of these studies have focused exclusively on the spiritual and therapeutic use of healers, shamans, or herbalists, and they have overlooked the popular use of these plants for medicinal purposes. This may be due to the continuing perception among researchers that the popular use of psychoactive substances is solely intended to alter the mind, which is why they regard it as less a therapeutic than a sacrilegious practice (Guzmán Chávez, 2013).
In various parts of the world, research has shown that people with a profane knowledge of conventional and traditional medicine use psychoactive substances to prevent or cure a range of health problems. In this regard, it is useful to conceptualize this popular use of psychoactive substances for medicinal purposes as a set of self-care knowledge, identified by different academic approaches as "popular medical health culture" (Polgar, 1963), "a profane system of reference" (Freidson \& de Miguel Rodríguez, 1978), "the popular sector of the family" (Kleinman, 1988), "self-care and self-attention" (Haro Encinas, 2000), or the "medical model of self-care" (Menéndez, 1984). These expressions refer to the knowledge of people about health and what they do to preserve and restore it, without the intervention of a professional physician or traditional healer, yet with the participation of members of their immediate social group. According to Menéndez (2018), self-care is the first real level of care, preceding the intervention of other medical models, such as those based on biomedicine and alternative medicines (such as shamanism, herbalism, and acupuncture). Self-care is defined as "the representations and practices the population uses at the subject and social group level to diagnose, explain, attend, control, alleviate, endure, cure, solve, or prevent the processes that affect their health in real or imaginary terms, without the central, direct, or intentional intervention of professional healers, even though the latter may be the benchmark for self-care activity" (Menéndez, 2009).

Self-care for a broad array of health problems (Arganis Juárez, 2005; Lozano \& Ortiz, 2011; Ramírez-de la Roche, Hamui-Sutton, Fuentes-García, \& Aguirre-Hernández, 2013), including emotional discomfort, depression, and anxiety disorders (Barić, Đorđević, Cerovečki, \& Trkulja, 2018; McPherson \& McGraw, 2013; Berenzon-Gorn, Alanís Navarro, \& Saavedra Solano, 2009), is a structural practice of societies (Haro Encinas, 2000; Menéndez, 2018). For example, in Mexico, Berenzon-Gorn, Saavedra Solano, \& Alanís Navarro (2009) found that, to treat emotional discomfort, women self-medicate with both herbal substances and biomedical pharmacology, in addition to engaging in self-care measures, such as physical exercise, rest, and behaviors involving self-control and relaxation activities. While they suffer from these ailments, they are medicated by friends or other close people, in addition to receiving support with housework or childcare, as well as expressions of love, empathy, accompaniment, resources and information, advice and guidance.

Several benefits have been linked to self-care, such as immediate care, empowerment, and the active role of patients in their own health care. However, self-care also entails risks (Ruiz, 2010), such as incorrect self-diagnosis, delays in seeking conventional medical advice, self-medication with adverse reactions, dangerous drug interactions, incorrect administration of substances, the wrong dose or choice of therapy, the masking of serious illnesses, and the 
risk of dependency and abuse. These risks may increase when self-care is based on false or unreliable information provided by the marketing of products whose efficacy has yet to be demonstrated in clinical studies, which in turn may be fraudulent (Hazekamp, 2018).

Self-treatment of anxiety by smoking marijuana appears to be a widespread practice in different parts of the world, yet with contradictory results. On the one hand, many recreational cannabis users and patients at medical marijuana dispensaries in the United States say that the drug relaxes them and has positive anti-anxiety results (Lowe, Sasiadek, Coles, \& George, 2019; Reinarman, Nunberg, Lanthier, \& Heddleston, 2011; Sexton, Cuttler, Finnell, \& Mischley, 2016), while other users report that smoking marijuana makes them anxious (Childs, Lutz, \& de Wit, 2017). These contrasting experiences depend on the concentration of the two main components of the cannabis consumed: tetrahydrocannabinol (THC, psychoactive element) and cannabidiol (CBD, non-psychoactive). The potency of cannabis is related to the concentrations of THC and CBD it contains. For example, if users smoke a plant with a higher concentration of THC, they will probably feel distress, yet relax if they smoke cannabis with a higher concentration of CBD. In this regard, scientific evidence indicates that THC, isolated from the plant, reduces anxiety at low doses, although it may increase it at high doses (Childs et al., 2017), whereas CBD, also isolated from the plant, decreases anxiety in all the doses at which it has been tested (Blessing, Steenkamp, Manzanares, \& Marmar, 2015). Conversely, it has been found that continuous self-medication with THC can create tolerance and that the efficacy attributed to CBD decreases if its composition includes residues of toxic solvents used during its extraction (Duffy et al., 2020), and if the labelling of the substance is incorrect or misleading as regards its purity (Hazekamp, 2018; Hazekamp \& Epifanova, 2017; Vandrey et al., 2015; Bonn-Miller et al., 2017). For example, in 2019, the US Food and Drug Administration found that the products of 22 marketing companies did not contain the CBD levels they advertised. ${ }^{1}$

Recently, the Mexican state stopped restricting the medicinal use of marijuana to certain indigenous peoples and authorized its use throughout the country. However, it has yet to publish regulations and norms for the therapeutic use of cannabis, or official standards for the quality control of the extraction of THC and CBD. It has also failed to allocate sufficient resources, or create public policies to provide top-quality professional medical services to ensure the therapeutic use of cannabis and its derivatives. In this context of legal ambiguity, the illegal market for medical drugs in Mexico, with a youth demand that increased by $60 \%$ between 1991 and 2014 (Villatoro et al., 2016), offers TCH

\footnotetext{
US Food and Drug Administration FDA, Warning Letters and Test Results for Cannabidiol-Related Products 2015/2019. https://www.fda.gov/newsevents/public-health-focus/warning-letters-and-test-results-cannabidiol-related-products (Retrieved June 21, 2020).
}

and $\mathrm{CBD}$ concentrates as medicinal oils for over a dozen health problems. In some cases, these products are sold with information on the recommended doses, interactions with other substances, and contraindications. All this happens without sufficient evidence in the emerging field of psychiatric cannabinoid therapeutics (Sarris, Sinclair, Karamacoska, Davidson, \& Firth, 2020). In this context, it is important to examine the uses of CBD and the experiences of its consumption from the point of view of consumers. From a phenomenological perspective, these people are not using CBD because of the black market for medical drugs, but because of the meanings CBD use has for them. Although these people may act within the framework of fraudulent marketing, what determines their CBD use is linked to their interpretations and definitions of their state of their health and of that substance, which they learned from their interactions with other people and their own experiences with the substance. Moreover, from the perspective of self-care models, these meanings, and what people do to prevent and treat health problems, form part of a set of popular self-care knowledge, which enables them to diagnose, treat, or prevent health problems. Below is a qualitative research report designed to identify and analyze the use of CBD for medicinal purposes and its attendant risks, as well as the associated treatments and self-care measures, in the self-care of anxiety from the perspective of working mothers in Mexico City.

\section{METHOD}

\section{Study design}

Based on the paradigm of social constructivism, a qualitative, situated (Denzin \& Lincoln, 2011), phenomenological study (Taylor \& Bogdan, 1987) was developed to focus on and understand the perspective of the female subjects in this study as social constructions derived from their social interactions, cultural practices, and appropriation of the conventional or alternative medical knowledge available to them. An attempt was made to obtain these socially constructed perspectives through in-depth interviews (Taylor \& Bogdan, 1987), since this technique, based on trust, can facilitate the free, confident, and detailed expression of the women's experiences with the use of CBD in the self-care of their anxiety.

\section{Subjects}

Eleven mestiza women with an average age of 40 participated. Table 1 shows that six lived with their partners, and that five were single householders. Eight had one child on average, while three had no children. Six women held undergraduate degrees, three had completed graduate studies, and two had finished high school. All of them worked or had worked with nonprofit organizations concerned with promoting the rights of indigenous people in Mexico City (CDMX). 


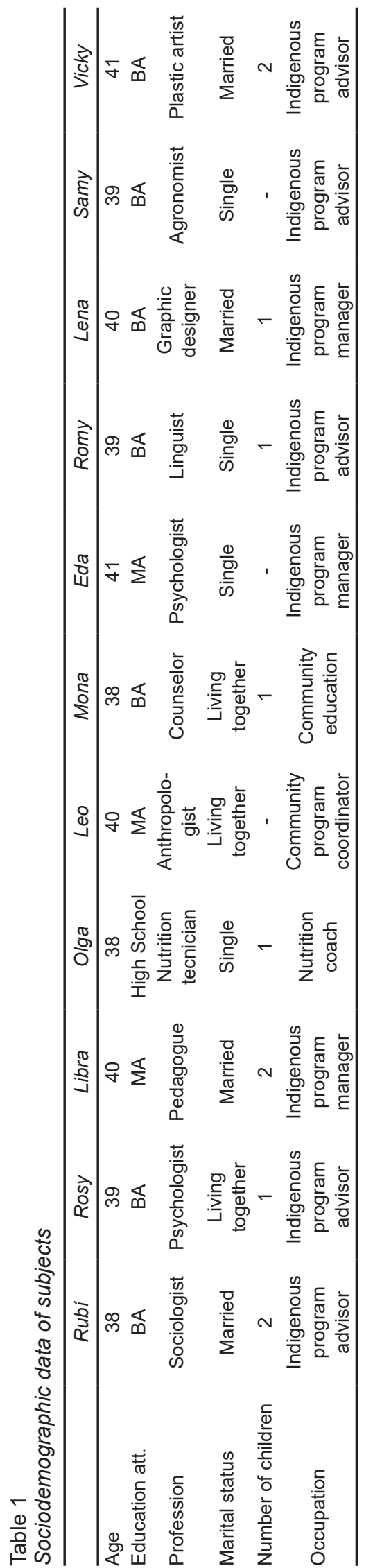

\section{Instruments}

To obtain the points of view of the subjects, in-depth interviews were conducted in two stages: rapport and implementation. In the former, face-to-face meetings were held between the researchers and each participant to enable the former to establish rapport, in other words, to gain the subjects' trust so that they would spontaneously share events or routines from their personal, family, or work life with them. During this stage of rapport, no attempt was made to obtain information on the medicinal use of CBD. However, when opinions, beliefs and practices regarding stressful situations and anxiety spontaneously emerged, the researchers recorded them in their field journals.

During the second stage, the authors of the research conducted the interviews in classrooms, private homes, or cubicles, always at the end of the subjects' working day. In the interviews, a semi-structured interview guide with open-ended questions was used for participants to describe their experiences of anxiety during the past 12 months: What problem did you have? How did you feel? What discomfort did you have? What did you do to take care of yourself? Did you discuss it with your friends, family, or health care professionals? What did they suggest? How did the remedy make you feel? Did it cause you any discomfort? And what problems did you have with continuing the treatment? Each answer was followed by impromptu questions that sought to detail the information provided. For example, after the answer to "What problems did you have?," the interviewers asked where and when they had happened, who else had been there and what the others had done. After the improvised questions, the next question on the interview guide was asked. The interview was conducted in two one-hour sessions. To check and expand on what the respondents had said, they were interviewed again three weeks later by two different researchers. If the information did not coincide or there were contradictions between the interviews, further questions were asked until the situation was clarified.

All the interviews were transcribed by people unconnected to the research and reviewed by the authors and subjects to ensure there were no mistakes and that the anonymity and what each subject had said was respected, which enhances the validity of the information obtained. In addition, the transcripts were filed on a computer, and assigned numerical codes not associated with indigenous names or groups. The lead investigator was the only one with access to the password for that computer.

\section{Procedure}

The aim was to find women who had reported experiences of anxiety and the way they had dealt with them, such as feeling scared or worried, looking for home remedies, paying for a consultation, diagnosis, and treatment by a 
health professional or taking an anxiolytic. To this end, a non-probabilistic convenience and snowball sampling was conducted. First, three women were contacted through convenience sampling because in a previous research project (Vega et al., 2015), they had mentioned that they were suffering from anxiety and that they had sometimes smoked marijuana to calm down or that doing so had made them anxious. At that time, they were working for a nonprofit and had been trained by the authors to conduct interviews and focus groups on emotional distress, discrimination, alcohol and drug use, violence, and access to medical services in indigenous communities living in Mexico City. Once they had been contacted, they were reminded of what they had said in the previous research project and asked whether they had been diagnosed with anxiety by a conventional doctor and whether they had used marijuana in the past 12 months. All three answered both questions affirmatively. They were then invited to participate in this research and asked to contact co-workers, friends and/or family members with anxiety and marijuana use in the past 12 months. They invited five other women, colleagues from another nonprofit, to a meeting where the authors explained the objectives of the research and interviewed them to so see whether they were eligible to participate in the research. Three subjects were excluded because they had not experienced anxiety or tried to find ways of coping with it. Women with these experiences were asked to participate in the research and invite more women with similar characteristics. They only managed to find three women with these characteristics, creating a total of 11 subjects. All of them were encouraged to invite more women, but none of them had more acquaintances eligible to participate in the research.

\section{Qualitative analysis}

The interviews and field diaries were analyzed using Atlas ti V7 software. This facilitated the development of conceptualizations of the information obtained, through its organization into conceptual categories created in a deductive and inductive way, according to the procedures of constant comparison and open and axial coding, provided by Grounded Theory (Strauss \& Corbin, 1990).

To ensure the reliability of the results, two researchers independently coded the transcribed interviews and the field diary. Separately, they categorized them deductively, assigning theoretical concepts from the proposed medical

Table 2

Classes, categories, and definitions of self-medication of anxiety

\begin{tabular}{|c|c|c|}
\hline Classes & Categories & Definitions \\
\hline \multirow[t]{5}{*}{$\begin{array}{l}\text { Self-medication refers to the identi- } \\
\text { fication of symptoms experienced, } \\
\text { their diagnosis, the selection and } \\
\text { prescription of a remedy, the dosa- } \\
\text { ge and its administration, self-care } \\
\text { measures, evaluation, and risks. }\end{array}$} & Symptoms experienced & $\begin{array}{l}\text { Apprehension (worries about coming calamities, feeling "on edge," concen- } \\
\text { tration difficulties). } \\
\text { Muscle tension (psychomotor agitation and restlessness, tension heada- } \\
\text { ches, tremors, inability to relax). } \\
\text { Vegetative hyperactivity (dizziness, sweating, tachycardia or tachypnea, } \\
\text { epigastric discomfort, vertigo, dry mouth). }\end{array}$ \\
\hline & Self-diagnosis & $\begin{array}{l}\text { The behaviors and biological signs that communicate symptoms and are } \\
\text { recognized as anxiety, pointing to permanent or serious stressful situations } \\
\text { among their causes. }\end{array}$ \\
\hline & Remedies & $\begin{array}{l}\text { All those substances or therapeutic practices of conventional, alternative } \\
\text { health services, domestic groups, friends and personal that are occupied, } \\
\text { combined, mixed, synthesized and updated to produce a favorable change } \\
\text { in anxiety, insomnia, and depression. } \\
\text { Dose. Amount of a substance, number of sessions, routines or time of the- } \\
\text { rapeutic prevention or health promotion practices. } \\
\text { Administration. The procedure whereby the person or group applies a remedy. }\end{array}$ \\
\hline & Evaluation & $\begin{array}{l}\text { Comparison and estimation of the usefulness of the remedies for anxiety, } \\
\text { such as the speed and effectiveness with which the remedy acts, as well } \\
\text { as its financial cost, adverse effects, and the duration of treatment. }\end{array}$ \\
\hline & Risks & $\begin{array}{l}\text { The probability that something harmful to health will happen, and the extent } \\
\text { of that damage, when using conventional therapies and self-medication. }\end{array}$ \\
\hline \multirow{3}{*}{$\begin{array}{l}\text { Diagnosis and treatment of conven- } \\
\text { tional healthservicesinterpretations } \\
\text { of the disease and proposed } \\
\text { treatments based on biomedical } \\
\text { pharmacology or psychological } \\
\text { therapies (psychoanalysis, cogni- } \\
\text { tive behavioral, etc). }\end{array}$} & $\begin{array}{l}\text { Self-medication with CBD } \\
\text { as alternative therapy }\end{array}$ & $\begin{array}{l}\text { Dosing and administration of CBD instead of the pharmacological } \\
\text { treatment of conventional medicine. }\end{array}$ \\
\hline & $\begin{array}{l}\text { Self-medication with } \\
\text { CBD as complementary } \\
\text { therapy }\end{array}$ & $\begin{array}{l}\text { Dosing and administration of CBD as a complementary therapy to } \\
\text { conventional treatments. }\end{array}$ \\
\hline & $\begin{array}{l}\text { Self-medication with CBD } \\
\text { with medical supervision }\end{array}$ & $\begin{array}{l}\text { Dosing and administration of CBD supervised by a doctor, as a } \\
\text { complementary therapy to pharmacological treatment. }\end{array}$ \\
\hline
\end{tabular}


models (such as self-care or self-medication) or from conventional or alternative medical literature (anxiety, stress, acupuncture) to the lines and paragraphs from the interview transcripts and field diaries that best illustrated them. These concepts were then regrouped into more general conceptual categories. The researchers also coded them inductively, deriving conceptual categories from the lines or paragraphs analyzed, using open and axial coding. Once they had finished encoding the field journals and each interview, the researchers compared their categorizations to identify similarities and differences, discuss them, keep, or delete categories, correct them, or incorporate them into an existing or new category, created to include their differences. The researchers then presented the categorization they had agreed on to the female subjects, who analyzed, discussed, and adjusted them in keeping with their views. The categories yielded by the analysis process are shown in Table 2: a) self-medication: experienced symptoms, self-diagnosis (permanent stressful situations and severe stressful situations), remedies (dose, administration, and evaluation) and self-care measures (prevention and health promotion: exercises, tai chi, yoga, meditation) and risks. b) diagnosis and treatment of conventional health services: self-medication with $\mathrm{CBD}$ as an alternative therapy; self-medication with $\mathrm{CBD}$ as a complementary therapy and self-medication with $\mathrm{CBD}$ with medical advice. This categorization is described in the results section, together with the self-care process.

\section{Ethical considerations}

All the participants received a letter with the name and work address of the authors, requesting their voluntary consent, and guaranteeing their confidentiality and anonymity in the interviews. The letter explained the objectives of the research, the interview technique, where it would be conducted and how long it would take. All the subjects were offered referral to psychological services in Mexico City, and they all voluntarily agreed to participate. Only the interviewer and the female subjects were present in the interviews. The material was transcribed by people unconnected to the research and checked by the authors to guarantee the anonymity of the subjects. In addition, the transcripts were filed on a computer and assigned numerical codes. The lead investigator was the only one with the password for this computer. Ethical approval was obtained from the Research Ethics Committee of the Ramón de la Fuente Muñiz National Institute of Psychiatry (Instituto Nacional de Psiquiatría Ramón de la Fuente Muñiz, INPRFM), on June 4, 2018: CEI/C/037/2018.

\section{RESULTS}

Table 1 shows that most subjects had children and worked, and nearly half were householders. This workload suggests stressful conditions, compounded by the subjects' lack of job security. Sometimes they are unemployed for a month, but at other times it is for three or four months, until the nonprofit secures funding to hire them.

The field journals show that most of them are responsable every day, for the housework (cleaning the house and cooking) and child raising. Before setting off for work, many of them wake up early, at five or six am, to have time to get ready, make breakfast, and take their children to school. When they arrive at work, they are sent to different parts of the city to follow up on projects with indigenous women who have been victims of domestic violence or are in trouble with the authorities. They meet with women, leaders of other nonprofits and the authorities to negotiate a solution to the problems. Although they have an eight-hour working-day, they sometimes work up to 10 hours. Then they go back home to do the housework, take care of their children, and help them with their homework.

All the women interviewed mentioned contact with conventional health services (psychologists, therapists, physicians, gynecologists, or psychiatrists) where they were diagnosed or told they had anxiety and depression. Only three women said they saw a psychiatrist every fortnight or month, for six or eight months of the year, while five reported that they had consulted therapists or other doctors every fortnight or month for one or two years while three had not seen either again for three years.

Women begin self-care practices as soon as they notice the first symptoms of anxiety, for example, when these signs continue for three or four days. So, they practice selfcare, specifically combining self-medication with self-care measures. Below is a description of the point of view of the subjects as the process of self-care of anxiety unfolds.

\section{Lived symptoms and self-diagnosis}

The women engaged in anxiety self-care practices before embarking on a period of medical consultations, especially when they noticed a continuation of the initial symptoms such as agitation or tension, insecurity, a feeling of nervousness, or of imminent danger or panic. These episodes were always triggered by serious stressful situations (such as job loss, the death of a loved one, or the breakdown/conflict of a relationship). Permanent stressful situations also caused anxiety, such as job instability, insufficient financial resources, or academic or job demands. Lena, who had previously received drug treatment for a depressive episode or depressive symptoms, gave an example of this:

\footnotetext{
"I had been off medication for almost two years, and then once again I felt nervous. My husband said I seemed very insecure and worried. I didn't want to go out or drive, much less smoke marijuana. I was very worried, I thought it was a sign of something bad that was going to happen. In fact, a month later I had serious work problems and my insecurity, fear, anxiety, and sleep problems got worse. All this happens when I am under a
} 
lot of pressure at work, although the last time was when someone close to me died."

The first reactions to the start of these symptoms were established through the analysis of their own bodily and emotional experience. Vicky pointed out the following:

\begin{abstract}
"It starts with my body being tense for a long time. I feel restless, worried, and can't be at peace. You lose your calm and concentration on what you are doing, you are absent, distracted. You just keep ruminating about the problem you have. You are sort of obsessive, you can't stop thinking about that, or you get distracted by something and then you're thinking about things all the time! At night-time, it gets worse. You can't fall asleep; you can't get any rest ... you aren't able to take your mind off things for long."
\end{abstract}

They all tried to deal with the symptoms, putting up with them during the day, doing housework or exercises that used an enormous amount of energy. As Mona noted:

\begin{abstract}
"The first time I felt like this, it was strong, although I was gritting my teeth. I tried not to give it so much importance, to distract myself and not talk about it, about my problem and the anguish that I felt, but my discomfort was still there in the background."
\end{abstract}

At night, their fears and worries kept them awake. For these women, the persistence of these symptoms was a sign of anxiety. Eda recalled:

\begin{abstract}
"As the days go by, you realize how anxious and scared you are.... I feel an emptiness in my stomach. I lose my appetite and my interest in everyday things. You stop feeling pleasure and joy and expect the worst. You don't trust anything, and above all, you do not trust yourself, as you lose your compass, your center. That is when you realize you are going to be anxious. You're not nervous that moment or at mid-day, it is a state of mind that takes over."
\end{abstract}

\section{The remedies}

All the women looked for a cure for their anxiety and sleeping problems among their family, friends, and their social networks on the Internet. Relatives recommended relaxing herbal teas (such as St. John's wort, passionflower, and valerian). Friends also suggested smoking marijuana, as it would make them drowsy and sleepy once the psychotropic effect set in. Friends or relatives gave them neck and back massages, listened to their fears and concerns, comforted them, offered them advice and some gave them Lyrica (pregabalin) pills to help them sleep, but also a controlled drug, which they called Rivotril (clonazepam). Some, but not all of them, were told to use this drug as a last resort for sleep, since taking it continuously would cause addiction and they would have to keep increasing the dosage. Then they would have to pay for a medical consultation to get a prescription and buy a controlled drug.

At the same time, the women tried to relieve their anxiety by using some of the therapies from so-called alternative medicines: acupuncture, herbalism, and aromather- apy, but they also incorporated self-care measures such as physical activity (running or walking), aerobics, yoga and/ or Tai Chi as well as breathing exercises, deep relaxation, and mindfulness meditation.

The Internet is a valuable resource for these women, because by participating in virtual social networks, they are able to share social and emotional support and information. For example, several of them found self-care measures on the Internet which they used to deal with their insomnia: keeping busy, restricting their coffee consumption to no later than $5 \mathrm{pm}$, having dinner two hours before bed, turning off electronic devices, and massaging certain parts of the forehead and arms and so on. They also found legal and illegal e-commerce sites for various remedies, including controlled drugs.

\section{Evaluation and risk of remedies}

All the women said that strenuous physical activities, relaxing infusions, and sleep hygiene measures helped them sleep a little, if their anxiety level was not high. Olga, another participant, remarked:

\footnotetext{
"It is difficult for me to organize my life so I can go to aerobics or yoga. I don't always have time and I stop doing it, I like to go to the group, it motivates me and then what I do is walk during the day as much as I can, when I do errands, my journey to work or school, I try to walk and get tired, or keep busy all the time."
}

Rubi explained what she does:

"For example, I go from scrupulously cleaning the house, to cooking, to shopping for groceries, I try to sweat ... to meditating or breathing for a few minutes. It gets you out of yourself for a moment and you do it to stop thinking or relieve the pressure at the time and relax, but what I need the most is to move, to wear myself out so as not to be so anxious. It gets rid of the stress better."

Several of the subjects mentioned the difficulty of continuously practicing these self-care measures, saying that they had domestic, academic, and work responsibilities that prevented them from continuing to do them. Sometimes they suspended them for days, but at other times for weeks or months, although they always resumed them as soon as they felt they were about to become anxious.

Some of the actions recommended by family and friends were effective for the women, but others were not. In some cases, they posed a risk to their health. For example, several of them delayed treatment with medical supervision, while others had adverse reactions to smoking marijuana, since it made them anxious, and they were unable to sleep. Some managed to sleep, but only by increasing their marijuana use several times a day. Some people took controlled medication for the first time, which made them drowsy and interfered with their concentration during the day. They combined several medications without knowing the dangerous interactions this could cause, for example, between relaxing herbs, 
Lyrica capsules (pregabalin that induces sleep and reduces anxiety), and controlled medication.

Eight women ended up continuing their medical consultations, while the remaining three participants no longer consulted anyone else. Of the latter, two were unemployed and lacked health insurance, while the other woman was an intern (Olga, Mona, and Eda). None of the three could afford a private consultation. All three coped with anxiety by increasing their marijuana use, from smoking once a day to smoking three or four cigarettes a day. They explained that this enabled them to sleep at night. If they woke up, they would smoke again, and then wait for the psychoactive effects to wear off so that they could go back to sleep. When they felt worse, they used controlled drugs to sleep, which they bought on the black market as Rivotril and Tafil (alprazolam).

\section{Diagnosis and treatment at conventional health services}

When they experienced persistent insomnia and anxiety, eight women sought a diagnosis and treatment for their health, specifically in private medical offices. Five consulted their trusted physicians, almost always general practitioners, or gynecologists, because this is cheaper than going to a psychiatrist and they were able to prescribe medicine for their anxiety (Vicky, Romy, Samy, Rosy, and Rubí). Two of them also used affordable psychological therapies (Samy, Rosy). Three consulted a psychiatrist described as dependable on their social networks (Lena, Leo, and Libra). In each case, the women were prescribed anxiolytics and antidepressants for six or eight months to a year. All the women rated the efficacy of the drugs and dosage in both interventions positively. One of the subjects remarked:

\footnotetext{
"I think I had very high levels of stress and anxiety because the herbs, meditation and needles didn't have any effect! It was only after I had had the treatment again that I managed to get back to normal and sleep and sleep!"
}

In addition to the medication, the women positively rated the professional service of the doctors who treated them, since they thought they were very responsible and carefully calculated the exact dose, which was determined by how anxious they felt and whether they slept well. They appreciated the fact that their doctors listened to them and advised them in their offices and as regards their medication in their everyday lives, specifying the dosage by phone or WhatsApp. The women said this helped reduce their anxiety, and enabled them to have more self-control, feel less insecure and scared, and resetting their sleep cycle. The use of these medical resources varies, depending on the women's finances and the severity of their symptoms. If the women develop acute symptoms and can afford to do so, they make an appointment with the doctor and buy prescription drugs, either at authorized pharmacies or on the black market. However, they also try to postpone medical treatment because they regard long-term medication as a risk to their health.

Seven of the eight women who sought care from private physicians pointed out that when the symptoms subsided for several months, or when they did not have enough money, they sought other diagnoses and therapies in alternative medicine, such as acupuncture, herbalism, iridology, and homeopathy. They also attempted to avoid or gradually stop taking pharmacological medications, relying on acupuncture or homeopathy, because they regarded them as more natural treatments. Lena remarked:

\begin{abstract}
"That time I saw a gynecologist to treat those symptoms caused by a hormonal change, but this time I was trying to find a way not to have to start drug treatment again, look for a psychiatrist, and spend money on that and the medicine. I was trying to cope with my anxiety with something "natural" because the pills also take a long time. They cause you harm, they fix one thing and mess something else up, they affect your health in other ways. I asked my family and friends, I looked on the Internet to find ways to boost my immune system, hormones, and skull acupuncture. I really tried everything."
\end{abstract}

This type of women recognizes the benefits of drugs, recommended doses, and professional treatment of doctors, but they are also aware of some of the risks (such as developing tolerance or anxiety during the gradual elimination of the substance) through personal experiences, those of relatives and friends or information obtained from the Internet. Therefore, these women want to stop taking drugs and postpone seeing a doctor, not out of ignorance, but because of their analyses of different experiences with drugs and other therapies. The same subject evaluated her experience with acupuncture:

\begin{abstract}
"When I took pills, I used to see the doctor with needles. I had great faith in her, she listened to me, and it was also like my psychological therapy. I saw her for two reasons: because she used to insert needles into me to counteract the side effects of the pills (such as antidepressants and anxiolytics) on other organs or functions of my body, and when I did not feel anxious anymore and wanted to stop using the pills and did not want to need clonazepam, I used the needles to relax for a while, without medication. In other words, I used them for maintenance."
\end{abstract}

In this case, postponing medical care does not mean neglecting health. On the contrary, it means delaying the side effects of medical drugs and relaxing longer without having to resort to them, at least temporarily.

\section{Self-medicating with CBD as alternative therapy}

Sometime after completing the treatment with family doctors, gynecologists, psychologists, and psychiatrists, the seven women reported relapses, suggesting that they had anticipated the need for further medication. Two women went back to seeing their doctors (Lena and Vicky), but five did not wish to repeat the drug treatment, at least not immediately, and attempted to continue dealing with their symptoms using alternative therapies. During this quest, Leo, Samy, Libra, Romy, and Rosy found information that 
led them to incorporate CBD use into the other treatments. The following case serves as an example.

\section{Leo and Libra}

Libra's circle of friends mentioned that a friend's mother had taken CBD to help her sleep. Libra talked to her and explained that she was taking clonazepam. The mother said that she had also taken the same thing, but that she had already stopped it and that she was now treating her insomnia using $\mathrm{CBD}$. She explained the following:

" $C B D$ is just to relax you, the one they prepare has no THC, ever. I thought THC had CBD, but they separate CBD from THC and sell it to you."

The mother gave Libra the address of a person who produced CBD tinctures illegally. She bought some, which was unlabeled and expensive, although cheaper than what she had bought from the psychiatrist. Libra told Leo about the CBD she had bought on the black market. Leo also bought a CBD dropper bottle. Leo commented on the dose and form of administration she used:

\begin{abstract}
"I was anxious, nervous about work and having difficulty sleeping. I bought it mainly to help me sleep. Libra told me that a friend's mom had stopped using clonazepam to help her sleep and was using $C B D$, the recommended dose being five to six drops at night. The first time I took it, I think I fell asleep after half an hour. I think I slept for about six hours in a row, but I'm not sure. The second night I took six drops and then about an hour later I had to get up to take another two drops because I could not get to sleep, and then I slept for about five hours. The third or fourth night, I think I took about 10 drops. I wanted to make sure I went to sleep, and it was odd, because I did fall asleep, but not very quickly. I woke up about three times during the night and had very vivid dreams."
\end{abstract}

Although Leo managed to fall as sleep with CBD, she did not sleep right through the night, and what struck her most was the subjective experience of dreams with CBD:

\begin{abstract}
"But I also had very strange dreams. I'm sure I woke up in the middle of my dreams and realized that I was dreaming, and I knew I had woken up in the middle of the dream and that I was consciously seeing what I was dreaming. I was there in the middle of the dream. I panicked because I was having a nightmare. I thought my house was in danger, and I saw intruders planning to do bad things and I wanted to warn my husband, but I couldn't wake up. I found it really hard to wake up!! I thought I had taken too many drops. CBD helps you for two or three days and then that dose is insufficient."
\end{abstract}

Leo attributes her experience to taking too much CBD. However, the purity of the CBD may also have played a role, since her cousin said that she knew that the CBD she had taken was not pure and that it had not helped her sleep.

Leo and Libra evaluated the effects of self-medicating with CBD on both the quality of their sleep and the immediacy of its effects on making them sleep. During their evaluation, they consulted with friends, health professionals, and the Internet. Leo took it up with her acupuncturist:
"After what had happened to me with the dreams, I consulted the acupuncturist, a surgeon. He knew about CBD and explained that the dreams I had experienced, the nightmares, were common, with CBD, and that exacerbated the altered emotional state I was going through. The doctor told me that according to traditional oriental therapy, that I had anxiety neurosis, a lack of control of the spirit because, as I understand it, I had certain specific imbalances of yin and yang in certain organs or systems, which explains my lack of concentration, lack of memory due to emotional stress, insomnia, lack of interest in things, and in addition, intense dream activity, feelings of déjà vu, premonitions, excessive unconscious activity, difficulty obtaining satisfaction, and well, I can't remember what else he told me. He explained, but it coincided with what I was feeling and what happened to me, especially when I used CBD at night."

Libra said she had read on the Internet that by itself, CBD was not a sedative like other insomnia medicine. It does not make you sleepy immediately; you are always fully conscious and alert during the day, and it helps you sleep at night.

Leo and Libra stopped taking CBD because it did not make them sleep quickly and went back to their usual doctors. As one of them explained:

\footnotetext{
"I think the CBD I bought was bad or they say it had THC; it never helped me sleep. So, I decided to look for a recommended psychiatrist. I found a very good doctor, I mean very good with drug treatment, for diagnosis and psychotherapy. She was the one who diagnosed me with depression with anxiety after doing the DSM test on me."
}

The case of Leo and Libra illustrates some of the risks of self-medication practices, such as postponing psychiatric consultation by experimenting with the wrong substance and dosage in an illegal context of marketing substances without guaranteeing their purity or safety.

After this experience with CBD, Leo and Libra consulted their doctors, who prescribed clonazepam and an antidepressant, with the idea of gradually removing the anxiolytic from their treatment, as they regarded it as a substance that creates dependency. After a year or two of psychiatric treatment, only one of them continues using small amounts of clonazepam. They no longer see psychiatrists regularly due to their work, but when they do consult them, they tell them the amount of antidepressants they have been taking and how they adjust the dose themselves. The psychiatrist evaluates the treatment they are adjusting on their own. $\mathrm{He}$ suggests that they try not to touch clonazepam and stresses that they should seek therapy if they suffer from anxiety or insomnia again because of unforeseen stressful events.

\section{Self-medicating with CBD as a complementary therapy}

Unlike Leo and Libra, three women continued to use CBD, even though it did not help them sleep. Samy, Rosy, and Romy explained that sometimes during the day, in stressful situations, they found it difficult to breathe, felt pressure in their chest, their hands became sweaty, and they were nervous. They interpreted these as anxiety symptoms and 
started taking CBD during the day, doing aerobic exercise or yoga. They point out that this relaxed them, making them less anxious and enabling them to work, write and do their household chores.

To deal with their insomnia and anxiety, they tried to obtain clonazepam on their own in two ways: by paying for a cheap medical consultation to get a prescription, as Samy did or through a virtual social media dealer. In both cases, they combined the anxiolytics with CBD. Rosy explains why she combines clonazepam with $\mathrm{CBD}$ :

\begin{abstract}
"I do it to save money, to make the CBD last longer. In Mexico it is hard to get excellent quality $C B D$ and it is more expensive, which is why I take it that way. Rivotril makes me sleep at night, and CBD calms me down during the day". Rosy
\end{abstract}

To be surer of the purity of CBD, two of these three women bought CBD from a dealer who sold Spanish and Canadian products on social networks. The other woman continued to buy CBD from a person who extracted it domestically and only sold it to their acquaintances. They all said that CBD calmed them down. Romy said:

\footnotetext{
"When I take it, it is because I feel very nervous or anxious and it calms you down. Well, you feel that it soothes you, it calms your anxiety, at least the physical symptoms of anxiety in your body."
}

She explains that she knew how much CBD to take from the recommendation on the bottle and from a PDF her dealer sent her by email. However, fearing that she might be found out by the Mexican police, she deleted the document and removed the label. She now relies on her memory and experience to calculate the dose she needs when she feels anxious during the day. She remarked:

\begin{abstract}
"I think there is a set amount, but I probably exceeded it, I think I took about four droppers a day. The whole dropper. Four times a day. The thing is that the first bottle I bought said that you should take it during the daytime. It said about 30 drops per dose, and you could take two a day and 30 drops are equivalent to a dropper. So, this one had no indications, but I assumed it was similar and nothing has happened to me."
\end{abstract}

They have also taken CBD concentrates in a cartridge, inhaling the vapor through a pen. Rosy describes her experience as follows:

\footnotetext{
"The most concentrated way I tried CBD was in a cartridge so you can smoke it in a pen, and I did feel the effect more quickly, but it has never felt like a benzodiazepine that sends you to sleep."
}

In these cases, the risks these women have run have to do with the substances and dosage chosen for their consumption and the interactions between them. They run the risk of developing tolerance to clonazepam (or alprazolam) and slowing its suppression. They may have trouble sleeping or very light sleep for several months. Although they consider that the CBD they have consumed is better quality, several studies warn about $\mathrm{CBD}$ with toxic residues mar- keted deceptively and fraudulently in various countries. In addition, the dosage of the substances continues to be left to the discretion of the consumer, in a context that requires them to remove the labels and recommended dosage.

\section{Self-medicating with $C B D$ with medical advice}

One of the three CBD users said that she subsequently had to consult a psychiatrist because her insomnia increased, and she had several work commitments. She said: "I had to get some sleep somehow, as they say ... I work, I pay taxes, I need to sleep, that's what Rivotril is for." At first, she was prescribed clonazepam and an antidepressant at night. Later, during her medical consultation, she mentioned self-medicating with $\mathrm{CBD}$, and the psychiatrist systematically incorporated the use of CBD to gradually replace the antidepressants and mentioned the precautions she would have to take. As Lena explained:

\begin{abstract}
"I did not contact the doctor about CBD, but she was part of a research group on the medicinal uses of cannabis. She knew about $C B D$, and I went to see her. I took a course of drugs, and when I felt better, I tried to lower the dose of the antidepressant and I asked her about using CBD. I wanted to know if I could use $C B D$ instead of the antidepressant, and gradually lower the dose of the antidepressant, and at this point, the doctor said I could, and even take them simultaneously. So, she incorporated a little CBD, two drops in the morning, two drops at night, and the antidepressant at night. The idea was that she was going to lower the antidepressant dose and CBD would be a backup. Depending on how anxious I felt, I could increase the CBD droplets, and I think it was pure CBD, I'm calm, and I can sleep, also because I'm not as anxious anymore."
\end{abstract}

The psychiatrist also recommended that she go to therapy and coordinate them with other therapies. She explained:

\footnotetext{
"As a result, I became more interested in cognitive behavioral issues, relaxation techniques, mindfulness, and biofeedback, so I could learn to regulate my physical-cognitive-emotional response to stress. In addition to continuing with yoga, exercises, and sleep hygiene: but since all this takes time, I do it on and off."
}

The previous testimonials reveal the cultural practices of self-care as a process of linking self-medicating with CBD with controlled drugs, under medical supervision, and with other therapeutics and self-care measures. In addition, women combine all the treatments suggested by professional doctors with personalized self-care. By taking what is most easily available and useful, women tailor the care that helps them feel better. As Samy remarked:

\footnotetext{
"Look, it is all useful. For a while I was more into psychoanalytic therapy. Also well, I think everything is complementary: therapy, cognitive behavioral techniques, having a physical exercise routine, taking antidepressants or CBD. I mean treating an anxiety disorder anxiety requires a holistic approach, not just antidepressants or CBD, not just meditation and needles. There comes a point when they may not be enough. It depends on your level of anxiety and if you are deeply depressed, as I was, it is not enough."
} 
The appointment also shows the permanent practicality of the participants and their capacity for the appropriation of and learning about the medicines or treatments they consider useful and effective.

\section{DISCUSSION AND CONCLUSION}

In just a few years, medicinal use of cannabidiol has become popular in various parts of the world where cannabis use has been legalized. In these places, CBD is marketed as a "miracle cure" for various health problems, including anxiety. Although there are preclinical studies citing the potential therapeutic efficacy of CBD for these conditions, there is a dearth of clinical trials demonstrating its efficacy. Consequently, many conventional medicine researchers and therapists in these countries do not recommend its medicinal use to public health professionals, nor do they approve of its popular use for medicinal purposes, as they consider it irresponsible and ignorant.

Conversely, the results of this qualitative research indicate that the use of CBD by the subjects constitutes a first level of medical care based on medical knowledge of self-care (Ramírez-de la Roche et al., 2013; Arganis Juárez, 2005). At this level, the subjects assume responsibility for their health, with or without medical supervision. They are an example of the patient who seeks information, analyzes their bodily reactions and emotional state, looks for remedies and uses them to deal with anxiety and sleeping problems. They also recognize the usefulness of consultation and the efficacy of conventional medicine, as well as their risks. It should be noted that among the subjects in this study, there is a tendency to delay psychiatric care and/or replace the use of psychiatric medications with alternative remedies or treatments as soon as possible. From a phenomenological perspective, it would be interesting to explore people's reasons for replacing drugs with CBD in more detail. In interviews conducted after this report, some subjects said that the consumption of biomedical medicines made them feel they were losing the control they should have over their sleep, thoughts, and emotional state, which they experienced as insecurity. For this reason, they prefer to replace drugs with $\mathrm{CBD}$, in addition to practicing self-care measures.

All this enables them to feel they are in control of their emotions, and that they can calm themselves down on their own. In this way, they act as sensibly as they can in a context of fraudulent marketing of impure substances not controlled by the state, without professional medical services that would provide them with better quality substances and guide their therapeutic use. There is a lack of public policies to provide professional, affordable medical services with trained personnel to inform medicinal users of cannabis, CBD, and THC of their uses, scope, and risks. One of the fundamental tasks of the health sector should be to improve its knowledge and liai- son with other therapies and to teach people and their groups of reference to self-care, in other words, to self-medicate and combine this with the best therapies available (Menéndez, 2018; Hazekamp \& Pappas, 2014).

At the same time, the results of this research provide information indicating that in everyday life, the efficacy attributed to CBD in controlled experimental contexts also depends on the legal context of the substance and the way it is used in each medical field (such as self-care, biomedicine, and acupuncture). For example, the ambiguous legal context of marijuana use encourages informal, illegal production and the commercialization of CBD of varying purity and efficacy, since the manufacture or commercialization of the substance is not controlled. Many of these products are available in Mexico, without the authorities inspecting how they were made, what they contain, or how they are marketed. Another factor that also influences the effectiveness of CBD is the way it is used in each therapy. For example, self-care does not only involve CBD. The latter is used as an alternative to avoid the health risks of biomedical pharmacology and its high cost, by combining it with self-care measures and other therapeutic alternatives, such as acupuncture. CBD is not regarded as a harmless panacea, since it can cause unwanted, disturbing dreams, a side effect which rarely occurs in conventional medicine. Although the latter therapy also does not use or recommend $\mathrm{CBD}$ as a miracle cure in its health services, the information reported shows that medical practice based on biomedicine is not entirely homogeneous, as some psychiatrists are gradually incorporating the use of CBD into their therapies and recommending its supervised combination with an array of medical knowledge. This type of practice should be encouraged and become a structural part of public health services.

\section{Financing}

None.

\section{Conflict of interest}

The authors declare they have no conflicts of interest.

\section{REFERENCES}

Arganis Juárez. E. N. (2005). La autoatención en un grupo de ancianos con diabetes residentes en Iztapalapa D.F. Cuicuilco, 12(33), 11-25.

Báez Cubero, L. (2012). El uso ritual de la "santa Rosa" entre los otomíes orientales de Hidalgo: el caso de Santa Ana Hueytlalpan. Cuicuilco, 19(53), 155-174.

Barić, H., Đorđević, V., Cerovečki, I., \& Trkulja, V. (2018). Complementary and alternative medicine treatments for generalized anxiety disorder: Systematic Review and Meta-analysis of randomized controlled trials. Advances in Therapy, 35(3), 261-288. doi: 10.1007/s12325-018-0680-6

Benítez, F. (1964). Los hongos alucinantes. México: Ediciones Era.

Benítez, F. (1980). Los indios de México. México: Ediciones Era.

Berenzon-Gorn, S., Alanís Navarro, S., \& Saavedra Solano, N. (2009). El uso de las terapias alternativas y complementarias en población mexicana con trastornos depresivos y de ansiedad: Resultados de una encuesta en la Ciudad de México. Salud Mental, 32(2),107-115.

Berenzon-Gorn, S., Saavedra-Solano, N., \& Alanís-Navarro, S. (2009). Estrategias 
utilizadas por un grupo de mujeres mexicanas para cuidar su salud emocional: autoatención y apoyo social. Salud Pública de México, 51(6), 474-481.

Blessing, E. M., Steenkamp, M. M., Manzanares, J., \& Marmar, C. R. (2015). Cannabidiol as a potential treatment for anxiety disorders. Neurotherapeutics, 12(4), 825-836. doi: 10.1007/s13311-015-0387-1

Bonn-Miller, M. O., Loflin, M., Thomas, B. F., Marcu, J. P., Hyke, T., \& Vandrey, R. (2017). Precisión de etiquetado de los extractos de cannabidiol vendidos en línea. JAMA, 318(17), 1708-1709. doi:10.1001/jama.2017.11909

Childs, E., Lutz, J. A., \& de Wit, H. (2017). Dose-related effects of delta-9-THC on emotional responses to acute psychosocial stress. Drug and Alcohol Dependence, 177, 136-144. doi: 10.1016/j.drugalcdep.2017.03.030

Denzin, N. K., \& Lincoln, Y. S. (2011). El campo de la investigación cualitativa. Barcelona: Gedisa.

Duffy, B., Li, L., Lu, S., Durocher, L., Dittmar, M., Delaney-Baldwin, E., ... Spink, D. (2020). Analysis of cannabinoid-containing fluids in illicit vaping cartridges recovered from pulmonary injury patients: identification of vitamin $\mathrm{E}$ acetate as a major diluent. Toxics, 8(1), 8. doi: 10.3390/toxics8010008

Fagetti, A., \& Reinoso Niche, J. (2019). La Santa Rosa y el uso ritual de enteógenos entre los pueblos indígenas. Elementos, 115, 23-27.

Fagetti, A., Garrett Ríos, M. G., \& Reinoso Niche, J. (2017). Interlocución y mediación: el uso ritual de la santa rosa entre los otomíes de la huasteca meridional (Mexico). Scripta Ethnologica, 39, 49-66. Retrieved from http:// www.redalyc.org/articulo.oa?id=14853734002

Freidson, E., \& de Miguel Rodríguez, J. M. (1978). La profesión médica. Un estudio de sociología del conocimiento aplicado. Barcelona: Península.

Guzmán Chávez, M. G. (2013). El culto del Santo Daime: Apuntes para la legalización del uso de sustancias psicoactivas en contextos ceremoniales en México. Revista de El Colegio de San Luis, 3(5), 56-89. doi: 10.21696/rcs1052013544

Haro Encinas, J. A. (2000). Cuidados profanos: una dimensión ambigua en la atención de la salud. In E. Perdiguero Gil, J. M. Comelles (Eds.). Medicina y cultura. Estudios entre la antropología y la medicina (pp. 101-162). Barcelona: Bellaterra.

Hazekamp, A. (2018). The trouble with CBD oil. Medical cannabis and cannabinoids, l(1), 65-72. doi: 10.1159/000489287

Hazekamp, A., \& Epifanova, S. (2017). Grote variatie in samenstelling cannabisolie noopt tot regels. Pharmaceutisch Weekblad, 152(44), 16-18.

Hazekamp, A., \& Pappas, G. (2014). Self-medication with Cannabis. In R. G. Pertwee (Ed.). Handbook of Cannabis (pp. 319-338). Oxford University Press. doi: 10.1093/acprof:oso/9780199662685.003.0017

Kleinman, A. (1988). The Illness Narratives: Suffering, Healing, and the Human Condition. New York: Basic Books.

La Barre, W. (1969). The peyote cult. Nueva York: The Shoestrings Pub.

Lowe, D. J., Sasiadek, J. D., Coles, A. S., \& George, T. P. (2019). Cannabis and mental illness: a review. European Archives of Psychiatry and Clinical Neuroscience, 269(1), 107-120. doi: 10.1007/s00406-018-0970-7

Lozano, E. J. O., \& Ortíz, C. B. (2011). Autoatención en salud oral en el pueblo Yanacona de los Andes del sur de Colombia. Acta Odontológica Colombiana, I(2), 85-102.
McPherson, F., \& McGraw, L. (2013). Treating generalized anxiety disorder using complementary and alternative medicine. Alternative Therapies in Health \& Medicine, 19(5), 45-50.

Menéndez, E. L. (1984). Hacia una práctica médica alternativa. Hegemonía y autoatención (gestión) en salud. Colección Cuadernos de la Casa Chata, núm. 86. México, CIESAS.

Menéndez, E. L. (2009). De sujetos, saberes y estructuras: Introducción al enfoque relacional en el estudio de la salud colectiva. Buenos Aires: Lugar Editorial.

Menéndez, E. L. (2018). Autoatención de los padecimientos y algunos imaginarios antropológicos. Desacatos, (58), 104-113.

Polgar, S. (1963). Health Action in Cross-Cultural Perspective. In H. E. Freeman, S. Levine, L. G. Reeder (Eds.). Handbook of Medical Sociology. Englewood Cliffs (pp. 397-419). New Jersey: Prentice-Hall.

Ramírez-de la Roche, O. F., Hamui-Sutton, A., Fuentes-García, R., \& AguirreHernández, R. (2013). Prácticas de autoatención en pacientes de los tres niveles de atención en instituciones de salud de México. Atención Familiar, 20(3), 91 95. doi: 10.1016/S1405-8871(16)30099-2

Reinarman, C., Nunberg, H., Lanthier, F., \& Heddleston, T. (2011). Who are medical marijuana patients? Population characteristics from nine California assessment clinics. Journal of Psychoactive Drugs, 43(2), 128-135. doi: 10.1080/02791072.2011.587700

Ruiz, M. E. (2010). Risks of self-medication practices. Current Drug Safety, 5(4), 315-323. doi: 10.2174/157488610792245966

Sarris, J., Sinclair, J., Karamacoska, D., Davidson, M., \& Firth, J. (2020). Medicinal cannabis for psychiatric disorders: a clinically-focused systematic review. BMC Psychiatry, 20(1), 1-14. doi: 10.1186/s12888-019-2409-8

Sexton, M., Cuttler, C., Finnell, J. S., \& Mischley, L. K. (2016). A crosssectional survey of medical cannabis users: patterns of use and perceived efficacy. Cannabis and Cannabinoid Research, 1(1), 131-138. doi: 10.1089/ can.2016.0007

Strauss, A., \& Corbin, J. (1990). Basics of qualitative research: Grounded theory procedures and techniques. London: Sage.

Taylor, S., \& Bogdan, R. (1987). Introducción a los métodos cualitativos de investigación: la búsqueda de significados. Barcelona: Paidós.

Vandrey, R., Raber, J. C., Raber, M. E., Douglass, B., Miller, C., \& Bonn-Miller, M. O. (2015). Cannabinoid dose and label accuracy in edible medical cannabis products. JAMA, 313(24), 2491-2493. doi: 10.1001/jama.2015.6613

Vega, L., Rendón, A., Gutiérrez, R., Villatoro, J., Vargas, A., Juárez, A., \& Trejo, S. (2015). Estudio sobre patrones de consumo de sustancias psicoactivas en población indígena residente y originaria de la ciudad de México. México: INPRFM-IAPA.

Villatoro, J., Medina-Mora, M. E., Martín del Campo, R., Fregoso Ito, D., Bustos, M. C., Resendiz Escobar, E., ... Cañas Martínez, V. (2016). El consumo de drogas en estudiantes de México: tendencias y magnitud del problema. Salud Mental, 39(4), 193-203. doi: 10.17711/SM.0185-3325.2016.023

Wasson, R. G. (1983). El hongo maravilloso: teonanácatl; micolatría en Mesoamérica. Traducido por Felipe Garrido. México: Fondo de Cultura Económica. 